\title{
GRG Profiles: Jackie D. Wood
}

\author{
Jackie D. Wood ${ }^{1}$
}

Published online: 4 May 2016

(c) Springer Science+Business Media New York 2016

I grew up in Commerce, Oklahoma (population 2500), in the extreme northeastern corner of the state and graduated with my high school class of 50 students in 1955. The great New York Yankees outfielder, Mickey Mantle (Number 7), graduated from Commerce High 6 years ahead of me.

Due to one of my great aunt's affiliation with the Eagle Picher Lead and Zinc Mining and Smelting Company, upon graduation, I received a scholarship to attend what was then Oklahoma A\&M University, now Oklahoma State University, in Stillwater, Oklahoma. I and three boyhood friends, finding ourselves in similar straits of no clue as to what we should do, consulted the Dean of Northeastern Oklahoma A\&M Community College in Miami, six miles south of Commerce. When confronted with the blank faces of four confused young male high school graduates to be, he suggested "why don't you boys enroll as engineering majors," which we did.

I enrolled at the community college for 2 years in order to make up deficiencies in math that would be required for transfer, as an engineering major, to Oklahoma A\&M. In the meantime, a second great aunt, who was a physician, began talking to me about studying medicine. Leland Keller, Ph.D., Professor of Biology at what was then Kansas State College of Pittsburg, now Pittsburg State University, was the Pre-med Director with a reputation for success in guiding his advisees to medical school admission at either the University of Kansas or the University of Oklahoma. Pittsburg State was 39.5 miles from Commerce,

Jackie D. Wood

Jackie.Wood@osumc.edu

1 Department of Physiology and Cell Biology, College of Medicine,, The Ohio State University, 305D Hamilton Hall, 1645 Neil Avenue, Columbus, OH 43210-1218, USA
Oklahoma. So I drove there and managed to gain an appointment with Dr. Keller.

\section{Leland E. Keller, Ph.D.}

Leland Keller embellished his academic functions, with a passion for collection and hording of antique medical devices. After retirement from his faculty job, he became curator of the Leland Keller Museum of Science and Quackery, which still shows up on a Google search. Following the interview with Dr. Keller, I enrolled at Pittsburg State, received a Bachelor's Degree in 1964 and Master of Science Degree in 1966.

Doctor Keller was my academic advisor during the years at Pitt State. He was a physiologist and director of two physiology courses, each of which had two "wet" 2-h labs per week. I was his graduate assistant for 2 years in handson student physiology laboratories covering systems, such as skeletal muscle preparations removed from frogs or preparations in living turtles demonstrating physiological and pharmacologic aspects of vagal control of the heart. I remain convinced that dedicated students learn physiology, which is basic to medicine, most effectively through handling and study of live tissues and organs.

Among Dr. Keller's scientific interests was investigation of the neurophysiology of "simple" invertebrate nervous systems. He maintained, in the laboratory, two species of large cockroaches, Periplaneta americana and Blaberus giganteus. I learned from him how to record, with microelectrodes, from the cockroaches' terminal abdominal ganglion. Neuronal cell bodies in this ganglion receive sensory input from the cerci, which underlies the typical escape behavior seen in cockroaches. Sensory nerves in the hairs of the cerci, which are fired when distorted by slight 
movement of the surrounding air or by substrate vibration, send axons that synaptically connect with the giant interneurons in the terminal abdominal ganglion. The information is processed by central synaptic circuitry that, in milliseconds, initiates running behavior. I studied electrical activity in the terminal ganglion as part of the research I did for my Master of Science degree. The title of my Master's Thesis was The Action of Nicotine in the Arthropod Nervous System.

Although Dr. Keller encouraged application to either medical school or a Ph.D. Program, I applied for admission to the Ph.D. Program in Physiology and Biophysics at the University of Illinois, Champaign-Urbana. My attraction to Illinois was the presence of Prof. C. Ladd Prosser on the faculty.

\section{Ladd Prosser, Ph.D., D.Sc. (Hon.)}

C. Ladd Prosser was a world authority on "simple" invertebrate nervous systems. His textbook of comparative animal physiology continues to be a Classic. I was accepted into the Ph.D. Program in May 1966 and accepted by Prof. Prosser as one of his graduate students in the same year.

I shared an office with eight of Ladd's graduate students on the 4th Floor of Burrill Hall on the University of Illinois campus. One day, Ladd walked into our office and handed me a reprint from Pflügers Arch.ges. Physiol. on the enteric nervous system (ENS). The article was from a Japanese investigator, who described electrophysiologic records that were interpreted to be action potentials recorded from ganglion cells in the myenteric plexus of rabbit small intestine [1]. The action potentials were greater than $20 \mathrm{~ms}$ in duration and Ladd thought they were smooth muscle action potentials, not from ENS neurons. He said to me, "Jack, because you have experience recording from insect neurons, I suggest you have a go at recording from the neurons inside the wall of the intestine." He went on to say that no one had ever recorded electrical activity from ENS neurons. With a large smile, he said, "neuronal cell bodies in the ganglia are like bunches of grapes and should be a piece of cake for you." I recall this statement as one of the rare occasions when he was mistaken. In fact, we now know that the ENS is a two-dimensional array of flat disklike neurons sandwiched between the longitudinal and circular muscle coats and between the circular muscle coats and the mucosa of most regions of the gut. Unlike other autonomic ganglia, the cell bodies of the ganglion cells are not in grape-like clusters. They lie edge-to-edge like a single layer of coins placed in a two-dimensional plane. Otherwise, Ladd was correct. Recording from the ENS neurons turned out not to be a real problem for me.
Ladd was involved in an ongoing international and sometimes rancorous debate on physiology of gastrointestinal smooth muscle at the time of my entry into his laboratory. The debate dealt with whether or not smooth muscle fibers in the tunica muscularis were electrically coupled one with another by gap junctions to form functional electrical syncytia, as in cardiac muscle. Cat small intestine was the model, used in the laboratory by Ladd's postdocs and graduate students for investigation of smooth muscle electrophysiology, as well as contractile mechanics. With availability of fresh cat intestine, I designed and built in the department's machine shop a Lucite recording chamber to maintain cat small intestinal preparations at body temperature in physiological media. I started recording with one or the other of two types of microelectrodes, platinum-iridium glass capillaries or electrolytically sharpened insulated steel, both with tips in the range of $1-5 \mu \mathrm{m}$. Neuronal electrical activity was amplified by a Tektronix (Type 122) preamplifier, displayed on a Tektronix (502A) oscilloscope and monitored on a loudspeaker. Continuous records were photographed with a Grass (Model C4) camera.

Practice was required to become reasonably skilled at microdissecting the intestinal wall to obtain preparations with a satisfactorily appearing myenteric plexus for electrophysiologic recording. Finally, the day came when I had my very first preparation setup in the tissue bath. The first time I touched the microelectrode tip to the surface of a ganglion, I heard on the loudspeaker and saw on the oscilloscope, the spontaneous discharge of action potentials that did not differ much from what I recorded in Kansas cockroaches. This was the first time electrophysiologic recording of neural discharge from neurons in the ENS had been done or at least reported in the literature. It "kickedoff" for me what has been a satisfying career of investigation of the neurophysiology and neuropharmacology of the ENS, which continues at the time of this writing. The paper was published in the American Journal of Physiology in 1970 [2]. Ladd insisted that I be listed as the sole author on the paper.

Getting the first paper on the ENS published did not go well and was discouraging for me as a budding investigator. Professor Mollie Holman, at Monash University in South Australia, reviewed the paper for the American Journal of Physiology and rejected it because she could not accept that spontaneous neuronal discharge occurred in autonomic ganglia. She evaluated the neuronal firing as an artifact. Fortunately for me, she did not have sufficient prestige to challenge Ladd, when he came to my defense, and the paper was accepted. Later, in 1983, Mollie and I were at a smooth muscle meeting on Hayman Island in Queensland, Australia. During a reception, she walked up to me and said, "Jackie, you were right and I was wrong 
about spontaneous neuronal discharge in enteric ganglia; I will apologize by escorting you to the bar and shouting you a beer."

\section{Williams College}

Because I wanted to continue research on the ENS and there were few, if any established laboratories in the USA or elsewhere with ENS neurophysiologic expertise, I forewent a postdoc and accepted a position at the rank of Assistant Professor in the Department of Biology, at Williams College in Williams Town, Massachusetts, in 1969. The physiologist in the Department was Samuel A. Matthews, Ph.D. He was the Samuel Fessenden Clarke Professor of Biology at the time.

I was finishing my dissertation when Ladd stepped into the small electrically shielded room, where I recorded from neurons, and said "Sam Matthews, at Williams College, called a few minutes ago to ask my advice on recruitment of his replacement, as the Department of Biology plans for his retirement." Sam Matthews and Ladd were old friends through Ladd's annual pilgrimage to his summer home in Woods Hole, Massachusetts, and research laboratory at the Woods Hole Marine Biological Laboratory. As was Ladd's habit, he squinted at my preparation, twiddled a couple of knobs on my oscilloscope and said, as he walked out, "Williams is the top one or two liberal arts colleges in the country, you should consider applying for the physiology position there." I got the job and moved to Williams Town in the summer of 1969.

I found, reserved for me, a totally satisfactory laboratory, start-up funding and colorfully painted office space in the Thompson Biology Building, when I arrived at Williams. My teaching assignment was a one semester systems and organs physiology course and a one semester course on cellular and comparative physiology, both with hands-on animal laboratories.

Sam Matthews left me a great legacy of equipment for the student teaching labs, and for that matter research, including new chart recorders, amplifiers, strain gages, and electronic stimulators generously donated by Mrs. Ellen R. Grass of the Grass Instruments Co. in Quincy, MA. My experience as a physiology laboratory teaching assistant with Leland Keller in undergrad courses and a NSF-funded summer course for high school teachers, as well as a physiology teaching assistant at the University of Illinois, made laboratory teaching in my first year at Williams straightforward and enjoyable. Moreover, I had a talented cadre of senior pre-med students as assistants.

My teaching load at Williams was moderate because the College expected faculty to do research and publish. I was never pressured by William C. Grant, the Chair, to obtain grant funding. Nevertheless, I learned at the University of Illinois that a young faculty member, like me, who wanted to do research must have success in obtaining grant support from national funding agencies such as the National Institutes of Health or the National Science Foundation.

My first research grant, submitted from Williams College, was entitled Function of the Enteric Nervous System and was funded by the National Science Foundation in mid-1970. The grant money enabled support for pre-med students to obtain research experience in my laboratory.

I found the pre-med students at Williams to be exceptionally bright and outstanding young men. Williams was not coed when I arrived. However, I had women in the classroom as exchange students from other quality New England liberal arts colleges, including Vassar, Wellesley, and Mount Holyoke. Many of the male students were enrolled in an honors program, which required completion and defense of a research thesis. Some of these students worked and published with me on the NSF grant [2,3]. Nevertheless, continuity of experienced hands in the laboratory was less than ideal because I generally had the students only for no more than a year before they were off to medical school. This became a factor in my decision to move to the University of Kansas School of Medicine and Medical Center in Kansas City, Kansas.

\section{University of Kansas Medical Center}

Before the annual meeting of the American Gastroenterological Association and Digestive Diseases Week grew to its present prominence, the major national meeting for gut-related science was the FASEB Meeting (Federation of American Societies for Experimental Biology) held annually in the spring in Atlantic City, New Jersey. A Williams College honors student and I were manning two posters at the 1970 FASEB meeting when Earnest B. Brown, Jr., the Chair of Physiology at the University of Kansas Medical Center, approached, had a look at the posters, and asked if I might be interested in a position in the Department of Physiology at the University of Kansas; he invited me to come for a visit. Because Kansas City was closer to home and the offer was attractive, I accepted the job and was appointed Assistant Professor in the Department of Physiology in 1971. My research and teaching of medical students went well there and I was promoted quickly through the academic ranks to Professor in 1979.

I gained my first experience in teaching physiology to first-year medical students in the first year at the KU Med Center. I used the opportunity to impress on the students that physiology is basic to medicine and understanding of how a system works normally is necessary for 
understanding what can go wrong, obtaining a diagnosis and development of a rational strategy for treatment.

I gained a genuine understanding of the meaning of "Rock Chalk, Jayhawk." Although I went to football games in Memorial Stadium on the main campus of the University of Kansas in Lawrence Kansas, Kansas football was a bit lacking. The "big red horde" from the University of Nebraska and from the University of Oklahoma would consistently embarrass the Jayhawks. However, it was a different story for Kansas basketball. The team went to the final four during my first year at Kansas and in 1973-1974 before I left to accept a job at the University of Nevada. Getting tickets for Kansas football was easy; getting tickets for basketball in Allen Fieldhouse on the main KU Campus in Lawrence Kansas was not.

I relished the teaching of medical students and apparently did it well, because I received the University of Kansas Chancellor's Award (including a \$1000.00 honorarium) for Excellence in Teaching in 1975 and a second teaching award in 1979, presented by the medical class of 1983. Research also went well as reflected by two major R01-level grants from the National Institute of Diabetes and Digestive and Kidney Diseases (NIDDK). One was for Study of Congenital Megacolon in Mice, and a second was titled Function of the Enteric Nervous System.

The congenital megacolon grant enabled my students and me to advance concepts of ENS neuropathy in Hirschsprung's disease [5-11]. Discoveries with the Hirschsprung's model prompted the mantra: "the gut does not work well if something is wrong in the ENS and does not work at all if the ENS is gone." The other grant for study of the function of the ENS received funding in 1972 and has been competitively renewed at the end of each 5-year cycle up to 2016. Moreover, while at the University of Kansas Med. Ctr., I received a 5-year NIH Career Development Award in 1974-1979 for support of ENS research.

The 1970s were prosperous times for NIH research funding, with pay lines somewhere around the 50th percentile. Sarah Kalser, the Program Director at NIDDK, actually telephoned and suggested that my productivity made me a qualified applicant and that I should apply for a Career Development Award. I was not aware and neither was the Kansas Med. Ctr. Administration of this category of NIH awards, now commonly known as "K" Awards. Combined with a fellowship from the Alexander von Humboldt Foundation in West Germany, the NIH Career Development Award enabled 2 years of fulltime research at the Physiological Institute of the Ludwig Maximilian University of Munich in Germany.

I worked at the Physiological Institute in 1976-1978 during the "Cold War," which divided Germany into the Deutsche Demokratische Republik (DDR) in the East and the Bundesrepublik Deutschland in the West. At the time, it was a policy of the Alexander von Humboldt Foundation to creatively introduce Humboldt fellows to Germany. During my first 2 months in Germany, I was required to brush up my German in a Goethe Language Institute in Grafing Stadt, which was about a 30-min S-Bahn ride outside of Munich. At the end of the Goethe language course, a busload of other fellows and I, including one other American, were accompanied by a Bavarian driver and a graduate student guide from Düsseldorf on a thirteen-city, two-week tour of Germany, including the DDR and East Berlin. I readily admit that crossing the Berlin Wall at Checkpoint Charlie from the American Sector into the Soviet Sector of Berlin was an emotional experience that brought back childhood impressions of World War II.

A relationship existed at the time between the West German military (Bundeswehr) and West German universities. What's more, my first postdoctoral fellow, Claus J. Mayer, Dr. Med., was a First Lieutenant in the Bundeswehr. Although he anticipated retirement as a General, he retired as a Colonel in 2005 due to the necessity of integration of East German officers following the fall of the Berlin Wall in 1990.

I was invited to present a paper on the ENS during the XXV International Union of Physiological Sciences Congress held in Munich in 1971, as well as a lecture in the Physiological Institute of the University of Munich. I met Claus Mayer and Dr. Med. Jürgen Riemer, one of his peers, during my visit to the Institute. They were much interested in my visit because they were attempting to record from neurons in the ENS and not having success.

Claus Mayer's commanding officer determined, and I agreed, that he should visit my laboratory. He was given the orders and arrived in Kansas City in 1972. My laboratory was well acquainted with nicotinic cholinergic neurotransmission in the ENS, which translated for the Bundeswehr into interest in nonreversible acetylcholine esterase inhibitors in warfare.

Claus Mayer remains one of my closest personal and professional friends. His "Boss," in 1972, was a General in the German airforce (Luftwaffe). Because German military pilots and air defense weapons specialists received training at Fort Bliss in El Paso, Texas, and George Airforce Base in Victorville, California, and because McDonald Douglas F-4 Phantom fighter planes were constructed in St. Louis, Missouri, Claus and I were able to travel free on cargo flights between Cologne, Germany, and airports in El Paso, Washington, DC, and Saint Louis in the USA. This enabled our work together in my laboratory in Kansas City and his laboratory at the Physiological Institute in Munich to continue for several years. The collaboration was exceptionally productive resulting in a number of seminal papers on electrical and synaptic behavior of ENS neurons that 
included the discovery of serotonin as a neurotransmitter for slow synaptic excitatory neurotransmission in the ENS [12-22].

\section{University of Nevada School of Medicine}

In 1979, I received an inquiry from the University of Nevada School of Medicine describing their recruitment efforts for a Chair of their Department of Physiology. The School of Medicine was reorganizing into a 4-year program in Reno, Nevada, in order to avoid export of their medical students to other Western university programs for the final 2 years of medical school. After three visits to Reno, I took the job in 1979.

The Seventh International Symposium on Gastrointestinal Motility was held in Iowa City, Iowa, on September 11-14 in 1979. Claus Mayer used a Luftwaffe cargo flight to cross the Atlantic and join me at the Meeting. We contributed a paper to the meeting on Comparison of the Action of 5-Hydroxytryptamine and Substance $P$ on Intracellularly Recorded Electrical Activity of Myenteric Neurons [23]. At the end of the meeting, we traveled on to Reno, where Claus remained for 3 months in order to help set up the ENS laboratory.

An appealing aspect of the job in Reno was the prospect for setting up a new department oriented to the neurobiology of the gut. I did so by recruiting faculty, who shared my research interest in what is recognized as a subspecialty of Gastroenterology, now identified as Neurogastroenterology $[24,25]$. The faculty included Helen J. Cooke, neurogenic secretion; Richard C. Rogers, central nervous control; Kenton M. Sanders, smooth muscle-interstitial cells of Cajal; Nelson Publicover, smooth muscle; Gerlinda Hermann, central nervous control. The Dean appointed me Chair of the search committee that led to hiring of David P. Westfall, Ph.D., from the University of West Virginia as Chair of the Pharmacology Department. With Dave Westfall and his faculty recruits in place, collaborative basic research related to the gut and autonomic nervous system flourished. Each member of the physiology department received R01-level funding from the NIH. My R01 on Function of the Enteric Nervous System was competitively renewed for five more years, as well as a second R01 on Presynaptic Receptors in Peripheral Ganglia, which was funded after my arrival at the University of Nevada (Fig. 1).

An attractive pleasure-related aspect of the job in Reno was the Western environment. It appeared to me as if a master architect had drawn a line separating Nevada and California, with spectacular Sierra Nevada mountains and an alpine environment to the west and a desert environment to the east. I perfected my skiing abilities on the slopes surrounding Lake Tahoe in winter and explored the abandoned "ghost" mining towns with a rented 4-wheel drive SUV on an occasional weekend during summer. I also made a few 3.5-h trips over Donner Pass to San Francisco. In fact, after my departure from the University of Nevada, Kenton Sanders, who succeeded me as the Chair of Physiology, appointed me to the advisory committee for an NIH program project grant that received funding. Kent always scheduled the advisory board meetings and my trips to Reno during ski season. It was satisfying for me that the Reno Program Project Grant on gastrointestinal smooth muscle was renewed last year to begin its 25 th year.

\section{The Ohio State University}

Earnest L. Mazzaferri, Sr., M.D., was recruited to the University of Nevada, Reno, from The Ohio State University College of Medicine as Chair of Internal Medicine during conversion of the medical school to a 4-year program. Ernie and I had research laboratories on the same floor of the Anderson Medical Sciences Building and became close friends after my arrival. In 1984, he was recruited back to Ohio State as the Chair of Internal Medicine.

One night, my bedside phone rang at 3:30 a.m. It was Ernie Mazzaferri. He apologized for overlooking the 3-h time difference and went on to tell me that The Ohio State University College of Medicine was initiating a Search for a Chairman of the Department of Physiology and encouraged me to apply. The abridged story is that I visited a few times, eventually accepted the job and moved to Columbus, Ohio, in 1985.

Since Ohio had no desert, abandoned ghost towns or comparable ski slopes, fun for me revolved around becoming a "Buckeye" and supporting Ohio State football and basketball. It has been great fun as the football team won national championships in 2002 and 2014. Attending a game with 108,000 fans in Ohio Stadium is something to be experienced. Basketball has not been bad either, with three Final Four appearances.

The Ohio State Department of Physiology had 24 fully funded faculty positions when I arrived. The Department had responsibility for teaching professional students in the College of Medicine, College of Dentistry, College of Nursing, College of Optometry, and School of Allied Medical Professions.

Numbers of faculty research grants in the Department of Physiology fell well below national norms in 1985. This was an issue for the College of Medicine Administration and was reflected by a statement in my letter of offer, which among other details, addressed the research deficiency as a priority. I was able to negotiate positions at 


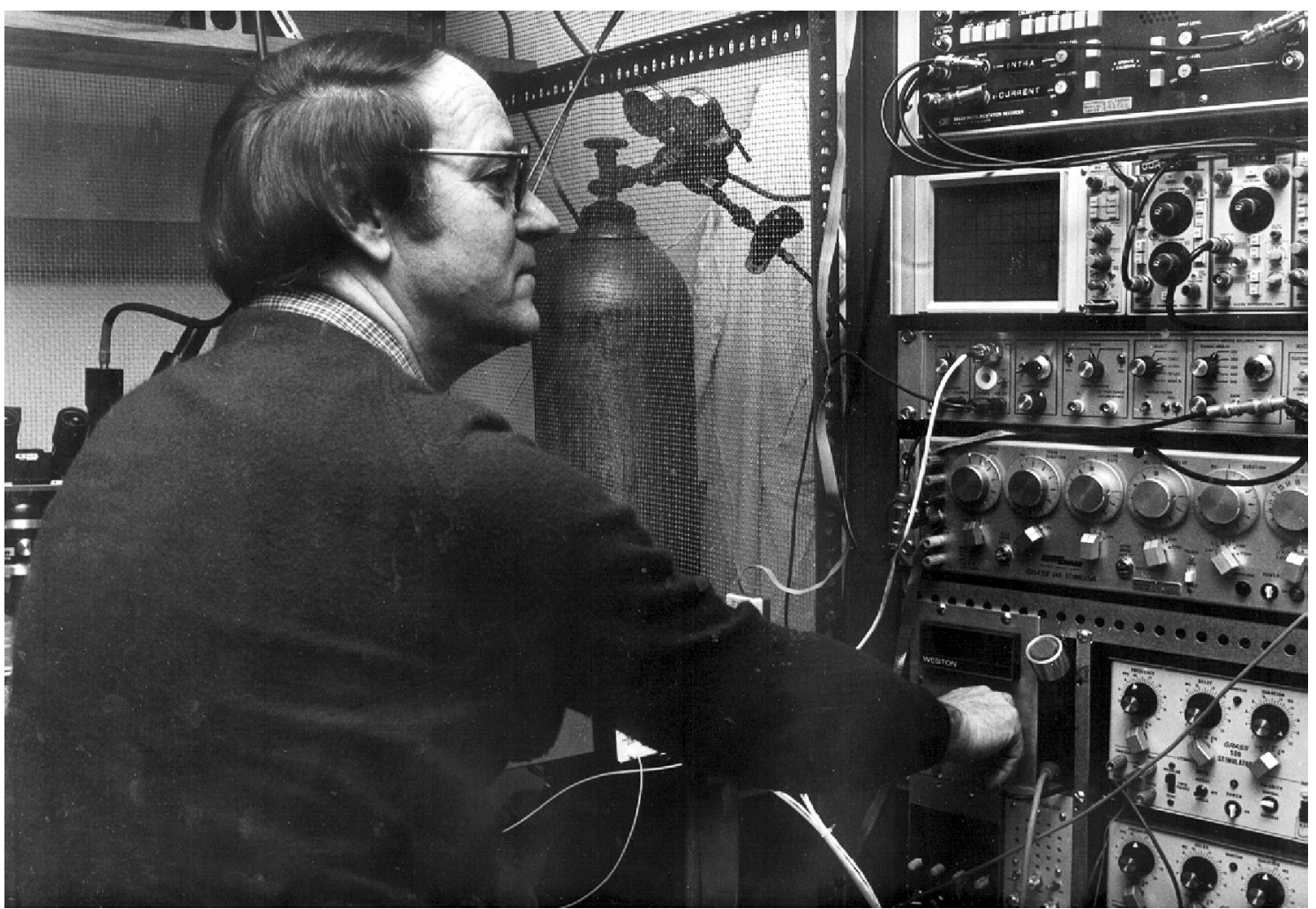

Fig. 1 Jackie "Jack" D. Wood at work in his laboratory in Reno, Nevada, in 1980

Ohio State for all members of the Reno group. Helen Cooke, Richard Rogers, and Gerlinda Hermann moved with me to Ohio along with three postdoctoral fellows and one Ph.D. student. Neither Kenton Sanders nor Nelson Publicover ended up accepting positions at Ohio State. Sanders replaced me as Chair in Reno and continues at present to lead a highly productive, nationally and internationally recognized department.

I stepped down as the Chair of Physiology at Ohio State in 1998, at which time grant funding had increased to eighteen NIH funded R01-level grants in the department. I remained at Ohio State as a Professor involved in research, teaching, and local, national, and international service on too many boards and committees to mention.

I enjoy teaching of medical students, but found the experience at Ohio State rather different from that at the University of Nevada, mainly in that class size is about 230 students compared with only 50 in Nevada, where I was personally acquainted with every student on a first name basis. In the Ohio State medical class, I know very few students by their first name. Nevertheless, I received a Merit Award $(\$ 10,000)$ that recognized excellence in research and teaching in The Ohio State University College of Medicine in 2007.

\section{Contributions to Digestive Science}

The dissertation for fulfillment of the requirements for my Master of Science Degree was a study of the neurophysiology of an insect central nervous system. Insight gained from the work on the "simple" nervous system led to my realization and continuous promotion of the fact that the heuristic model for the ENS, like invertebrate nervous systems, is that of an independent integrative nervous system. My first published study of the ENS was done at the Marine Biological Laboratory in Woods Hole, MA. I had accompanied Dr. Prosser on his annual visit to the Marine Biological Laboratory in Woods Hole, MA, which at the time was a mecca for study of the neurophysiology of independent integrative nervous systems. Research done at Woods Hole resulted in my first paper titled, Electrophysiological and Pharmacological Properties of the Stomach of the Squid, Loligo pealei [26]. The paper describes remarkable similarities between cephalopod and mammalian gastrointestinal tracts in terms of physiology of the smooth muscle and ENS neural control of motility. I concluded that expression of like physiological characteristics between cephalopods and mammals reflects parallel evolution of two digestive systems in vastly different 
animals under very similar selective pressures. Squid, living in the ocean, evolved into pelagic carnivores from molluscan filter feeders, such as mussels, clams, and oysters, under selective evolutionary pressures that were much the same as took place in the evolutionary history of carnivorous mammals on land.

The next paper in 1970 was the first to describe the electrical behavior of neurons in the cat ENS [2]. In 1981, in view of rapidly emerging evidence that the ENS expressed independent neurophysiologic properties akin to the mammalian brain and spinal cord, I coined the now universally accepted term, brain-in-the-gut, in a review in the 1981 Annual Review of Physiology [27].

Early on, my laboratory team demonstrated the fundamental importance of inhibitory musculomotor neurons in the ENS. We were first to show that subpopulations of ENS inhibitory musculomotor neurons were spontaneously firing, an important function of which is continuous suppression of the autogenous behavior of the smooth musculature. The work established the concept that the various patterns of intestinal motility are dependent on integrated disinhibition of the intestinal circular muscle coat. In the normally functioning bowel, integration of the activity of inhibitory motor neurons determines four key events, first of which is whether or not an electrical slow wave triggers a contractile response in the intestinal circular muscle coat. Secondly, neurogenic inhibitory control decides the force of the contractile response triggered by an electrical slow wave. Thirdly, the distance over which muscle action potentials and associated contractions spread from muscle fiber to fiber via the gap junctions that underlie the electrical syncytial properties of the smooth muscle is determined by integrated control of firing of inhibitory musculomotor neurons. Fourthly, turning on and off of inhibitory motor neurons determines direction of spread of action potentials and associated contractions along a segment, which can be in the oral or aboral direction according to the motility pattern.

Our investigation of inhibitory musculomotor neurons led us to discard the dogma that the constricted terminal segment and megacolon in Hirschsprung's disease reflected overgrowth of cholinergic innervation in the aganglionic terminal segment. Instead, we showed that the constricted terminal segment resulted from myogenic contractile activity in the congenital absence of the ENS and its population of inhibitory musculomotor neurons. These data are published in 19 peer-reviewed journals [4-7].

Teams in my laboratory were the first to demonstrate the fundamental importance of ENS secretomotor neurons in terms of neurogenic control of glandular secretion of $\mathrm{NaCl}$, $\mathrm{H}_{2} \mathrm{O}$, and $\mathrm{HCO}_{3}$. Translational significance of these discoveries are firstly, any condition that elevates excitability of secretomotor neurons leads to a diarrheal state (e.g., infectious diarrhea), and second, conditions in which excitability of secretomotor neurons is suppressed lead to constipation (e.g., opioid-induced constipation). Our data on neurogenic secretion are published in 20 peer-reviewed journals [28-32].

In early collaboration with Claus Mayer in Munich, my laboratory was first to describe slow excitatory postsynaptic potentials (slow EPSPs) in the ENS. We identified: (1) the receptors for slow EPSPs; (2) morphologies of neurons expressing the receptors; (3) intraneuronal signal transduction cascades for slow EPSPs; (4) membrane channels involved; (5) neuronal expression of excitatory receptors for paracrine mediators released from enteric immune/inflammatory cells, such as histamine and mast cell proteases. We published multiple papers on the cellular biology of inhibitory postsynaptic potentials (IPSPs) in the ENS. Our data on neurotransmission are published in over 95 peer-reviewed journals [33-39].

\section{Owen C. Peck, M.D.}

In the late 1980s, my group began investigation of inflammatory bowel disease. Our attention to ulcerative colitis was motivated by Owen C. Peck, M.D., who had moved to the University Of Nevada School Of Medicine in Reno from his position in Internal Medicine at the Palo Alto Clinic in Southern California in 1978. Owen had a sustained interest in inflammatory bowel disease that projected back to his time on the staff of the Palo Alto Clinic and two famous patients that received treatment there. One was the Nobel Laureate and pioneering nuclear scientist, Earnest Lawrence. The other was Edward Teller, a Hungarian-born American theoretical physicist, who has been referred to as "the father of the hydrogen bomb." Both of the famous scientists suffered from ulcerative colitis, exacerbation of which Owen felt was related to stressful life events.

As an undergraduate, Owen attended the University of Kansas where he was an All Star basketball player for the famous Kansas coach, Phog Allen. Aside from his reputation as a winning coach, Phog Allen was also trained as a Doctor of Osteopathic Medicine. After basketball, Owen was admitted to medical school at the University of Kansas. He attributes his career in medicine to Phog Allen, who was colloquially called "Doc."

After I was ensconced in Reno, Owen would show up unannounced in my office and ask, "Jack, what do you know about ulcerative colitis?" My reply would be, "very little," but if you would like to study it effectively, an animal model will be essential."

While at an NIH Study Section Meeting in Bethesda, $\mathrm{MD}$, I learned of a meeting focused on inflammatory bowel 
disease and colon cancer in a nonhuman primate model that was to be held at Oak Ridge Associated Universities, in Oak Ridge, Tennessee, in 1984. I mentioned the meeting to Owen. His response was a typical, "I will go." He went and upon return to Reno could not wait to tell me that the meeting was focused on a monkey that developed spontaneous colitis and appeared to be the model we were looking for. Proceedings of the Oak Ridge Meeting were published with the title, Is the Marmoset an Experimental Model for the Study of Gastrointestinal Disease? In Digestive Diseases and Sciences as a Supplement (Vol. 30, Number 12, 1985).

It so happened at the time that a colony of thirty marmosets (now officially classified as tamarins) was being studied for reasons other than inflammatory bowel disease at Texas A\&M University in College Station, Texas. The investigators in Texas had finished their work and were looking to liquidate the colony. Financed by donations from Owen's patients in Reno, we acquired the monkeys. At the time, I was in the process of moving to The Ohio State University, where we housed the colony of tamarins.

Work on the colony of tamarins was funded at first by a seed grant from Ohio State and later by an NIH R01-level grant. We terminated the work on cotton-top tamarins in 1995, when the NIH did not renew the grant.

Most of the evidence obtained from our studies of the only known nonhuman primate model for spontaneous colitis and colon cancer supported a hypothesis of a braingut connection in colitis [40-44]. Severe colitis was found in 80-85 percent of the tamarins in the Ohio State colony during semiannual colonoscopically obtained biopsies. We found colitis in biopsies from young tamarins at 6 months of age when the colon could first be accessed with 7.9-mm pediatric endoscopes. As the animals aged, we would begin to find low-grade dysplasia, high-grade dysplasia, and eventually cancer, which became obstructive.

With a desire to learn if there might be a genetic predisposition to colitis in the cotton-top tamarin model, we managed to capture and obtain colonoscopic biopsies from cotton-top tamarins, living wild in their natural habitat in Colombia, SA. As we were planning the work, I was concerned that the wild tamarins might have some form of infectious colitis that we would be unable to distinguish from ulcerative colitis. However, we never found any indications of colitis in biopsies removed from over 100 wild-living tamarins. In the midst of the work on wildcaught tamarins, we made a serendipitous discovery of severe colitis in each of 29 cotton-top tamarins held in outside cages at frigid nighttime temperatures in a zoo in Cali, Colombia, S.A. All indications of colitis (elevated immune cells, crypt abscesses, mucous depletion, etc.) subsided after transfer from the Cali Zoo environment to their natural tropical habitat in Northern Colombia. This led us to suggest that stress was a factor in the initiation and progression of colitis to cancer in the tamarin model.

In testing a hypothesis that substance $\mathrm{P}$ released from spinal sensory afferents triggered colitis, we found that twice-daily oral dosing with a nonpeptide neurokinin-1 antagonist suppressed the acute inflammatory response in the colon of cotton-top tamarins when the tamarins were removed from their natural habitat to the colitis-inducing environment of the zoo in Cali.

Our general working hypothesis continues to be that a brain-mast cell connection is involved in the initiation of colitis. Physical or emotional stress degranulates enteric mast cells to release simultaneously both chemical signals to the enteric nervous system and chemical factors that attract influx of inflammatory cells.

During the course of the work on triggers for intestinal inflammation we discovered mechanisms by which spinal afferent innervation degranulates enteric mast cells to release inflammatory mediators that feedback and sensitize the afferent terminals to their various stimuli, as well as actions of Clostridium difficile toxin [38, 45]. We suggested that this form of sensitization of enteric sensory nerves might be a significant factor in visceral pain syndromes.

\section{Pharmaceutical Industry}

Throughout most of my career, I have shared my knowledge of the ENS and the investigative skills of my teams of students and postdoctoral fellows in collaborative ventures with the pharmaceutical industry, with an objective of understanding mechanisms of actions of drugs in the context of development of treatments for functional gastrointestinal disorders. Drugs we have worked on in this category include cisapride (Propulsid ${ }^{\circledR}$ ), tegaserod $\left(\right.$ Zelnorm $\left.{ }^{\circledR}\right)$, alosetron (Lotronex $\left.{ }^{\circledR}\right)$, and lubiprostone $\left(\right.$ Amitiza $\left.{ }^{\circledR}\right)$ [46-48].

\section{Conclusions}

Three important factors enabled my success in teaching of physiology in academia and the progressive lifelong advancement of my scientific productivity in relation to the ENS. First was the quality of the education, training, and hands-on experience I received at Kansas State University of Pittsburg and University of Illinois, Champaign-Urbana. Second was the outstanding character and talent of the colleagues, students, and graduate fellows I have been privileged to work with in the laboratory. Third has been 40 years of support from the National Institute of Diabetes and Digestive and Kidney Diseases (NIDDK). 


\section{References}

1. Yokoyama S. Aktionspotentiale der Ganglienzelle des Auerbachschen plexus im kaninchendünndarm. Pflügers Arch Gesamte Physiol Menschen Tiere. 1966;288:95-102.

2. Wood JD. Electrical activity from single neurons in Auerbach's plexus. Am J Physiol. 1970;219:159-169.

3. Wood JD, Harris BR. Phase relationships of the intestinal muscularis: effects of atropine and xylocaine. J Appl Physiol. 1972; 32:734-737.

4. Wood JD, Marsh DR. Effects of atropine, tetrodotoxin and lidocaine on rebound excitation of guinea-pig small intestine. $J$ Pharmacol Exp Ther. 1973;184:590-598.

5. Wood JD. Electrical activity of the intestine of mice with hereditary megacolon and absence of enteric ganglion cells. Am J Dig Dis. 1973;18:477-488.

6. Brann L, Wood JD. Motility of the large intestine of piebaldlethal mice. Am J Dig Dis. 1976;21:633-640.

7. Wood JD, Brann LR, Vermillion DL. Electrical and contractile behavior of large intestinal musculature of piebald mouse model for Hirschsprung's disease. Dig Dis Sci. 1986;31:638-650.

8. Wood JD, Brann LR. Pharmacological analysis of rebound excitation in large intestine of piebald mouse model for Hirschsprung's disease. Dig Dis Sci. 1986;31:744-752.

9. Wood JD, Brann LR, Daugherty CK. Regional effects of hypoxia and hypothermia on rebound excitation in large intestine of piebald mouse model for Hirschsprung's disease. Dig Dis Sci. 1986; 31:859-864.

10. Brann L, Furtado D, Migliazzo CV, Baxendale MJ, Wood JD. Secondary effects of aganglionosis in the piebald-lethal mouse model of Hirschsprung's disease. Lab Anim Sci. 1977;27:946-954.

11. Wood JD, Mayer CJ. Slow synaptic excitation mediated by serotonin in Auerbach's plexus. Nature (Lond). 1978;276:836837.

12. Grafe P, Mayer CJ, Wood JD. Evidence that substance P does not mediate slow synaptic excitation within the myenteric plexus. Nature (Lond). 1979;279:720-721.

13. Wood JD, Mayer CJ. Adrenergic inhibition of serotonin release from neurons in guinea pig Auerbach's plexus. J Neurophysiol. 1979;42:594-603.

14. Grafe P, Mayer CJ, Wood JD. Synaptic modulation of calciumdependent potassium conductance in myenteric neurones in the guinea-pig. J Physiol (Lond). 1980;305:235-248.

15. Wood JD, Mayer CJ. Intracellular study of tonic-type enteric neurons in guinea pig small intestine. J Neurophysiol. 1979;42: 569-581.

16. Wood JD, Mayer CJ. Serotonergic activation of tonic-type enteric neurons in guinea pig small bowel. J Neurophysiol. 1979;42: 582-593.

17. Grafe PG, Wood JD, Mayer CJ. Fast excitatory postsynaptic potentials in $\mathrm{AH}$ (Type 2) neurons of guinea pig myenteric plexus. Brain Res. 1979;163:349-352.

18. Mayer CJ, Wood JD. Properties of mechanosensitive neurons within Auerbach's plexus of the small intestine of the cat. Pflugers Arch. 1975;357:35-49.

19. Mayer CJ, Riemer J, Wood JD. Elektra-physiologische untersuchungen zur bedeutung der intramuralen neuren des darmes unter besonderer berucksightigung ihrer inhibitorischen. Wirkungen Bundesministeriums der Verteidigung vom Dokumentationszentrum der Bundeswehr Bonn. 1975;8:1-191.

20. Wood JD, Mayer CJ, Grafe P. Electrical slow waves in guineapig myenteric neurons. J Auton Nerv Syst. 1982;5:247-249.

21. Wood JD, Mayer CJ, Ninchoji T, Erwin DN. Effects of depleted calcium on electrical activity of neurons in Auerbach's plexus. Am J Physiol. 1979;236:78-86.
22. Wood JD, Mayer CJ. Discharge patterns of enteric neurons of the small intestine of the cat, dog and guinea-pig. In: Daniel EE, ed. Proceedings IV international symposium on gastrointestinal motility. Vancouver, BC: Mitchell Press; 1974:387-408.

23. Wood JD, Grafe P, Mayer CJ. Comparison of the action of 5-hydroxytryptamine and substance $\mathrm{P}$ on intracellularly recorded electrical activity of myenteric neurons. In: Christensen J, ed. Gastrointestinal motility. New York: Raven Press; 1980: 131-138.

24. Wood JD. Neurogastroenterology: perspectives on a subspeciality. In: Tsuchiya M, Matsuo Y, Yutaka K, Muto T, eds. Gastrointestinal function regulation and disturbances. Tokyo: Excerpta Medica; 1996:3-24.

25. Wood JD, Alpers DH, Andrews PL. Fundamentals of neurogastroenterology. Gut. 1999;45:II6-II16.

26. Wood JD. Electrophysiological and pharmacological properties of the stomach of the squid Loligo pealii (Lesueur). Comp Biochem Physiol. 1969;30:813-824.

27. Wood JD. Intrinsic neural control of intestinal motility. Annu Rev Physiol. 1981;43:33-51.

28. Cooke HJ, Shonnard K, Wood JD. Effects of neuronal stimulation on mucosal transport in guinea pig ileum. Am J Physiol. 1983; 245:290-296.

29. Baldassano S, Liu S, Qu MH, Mule F, Wood JD. Glucagon-like peptide-2 modulates neurally evoked mucosal chloride secretion in guinea pig small intestine in vitro. Am J Physiol Gastrointest Liver Physiol. 2009;297:800-805.

30. Fei G, Wang YZ, Liu S, et al. Stimulation of mucosal secretion by lubiprostone (SPI-0211) in guinea pig small intestine and colon. Am J Physiol Gastrointest Liver Physiol. 2009;296:823832.

31. Sun X, Wang X, Wang GD, et al. Lubiprostone reverses the inhibitory action of morphine on mucosal secretion in human small intestine. Dig Dis Sci. 2011;56:330-338.

32. Fei G, Fang X, Wang GD, Liu S, Wang XY, et al. Neurogenic mucosal bicarbonate secretion in guinea pig duodenum. $\mathrm{Br} J$ Pharmacol. 2013;168:880-890.

33. Christofi FL, Tack J, Wood JD. Suppression of nicotinic synaptic transmission by adenosine in myenteric ganglia of the guinea-pig gastric antrum. Eur J Pharmacol. 1992;216:17-22.

34. Liu S, Hu HZ, Gao N, et al. Neuroimmune interactions in guinea pig stomach and small intestine. Am J Physiol Gastrointest Liver Physiol. 2003;284:154-164.

35. Liu S, Qu MH, Ren W, et al. Differential expression of canonical (classical) transient receptor potential channels in guinea pig enteric nervous system. J Comp Neurol. 2008;511:847-862.

36. Nemeth PR, Zafirov D, Wood JD. Forskolin mimics slow synaptic excitation in myenteric neurons. Eur J Pharmacol. 1984; 101:303-304.

37. Palmer JM, Wood JD, Zafirov DH. Elevation of adenosine $3^{\prime}, 5^{\prime}$ phosphate mimics slow synaptic excitation in myenteric neurones of the guinea-pig. J Physiol (Lond). 1986;376:451-460.

38. Wang GD, Wang XY, Liu S, et al. Innervation of enteric mast cells by primary spinal afferents in guinea pig and human small intestine. Am J Physiol Gastrointest Liver Physiol. 2014;307: 719-731.

39. Wang GD, Wang XY, Zou F, et al. Mast cell expression of the serotonin 1A receptor in guinea pig and human intestine. Am J Physiol Gastrointest Liver Physiol. 2013;304:855-863.

40. Clapp NK, McArthur AH, Carson RL, Henke MA, Peck OC, Wood JD. Visualization and biopsy of the colon in tamarins and marmosets by endoscopy. Lab Anim Sci. 1987;37:217-219.

41. Stonerook MJ, Weiss HS, Rodriguez MA, et al. Temperaturemetabolism relations in the cotton-top tamarin (Saguinus oedipus) model for ulcerative colitis. J Med Primatol. 1994;23:16-22. 
42. Wood JD, Peck OC, Tefend KS, et al. Colitis and colon cancer in cotton-top tamarins (Saguinus oedipus oedipus) living wild in their natural habitat. Dig Dis Sci. 1998;43:1443-1453.

43. Wood JD, Peck OC, Tefend KS, et al. Evidence that colitis is initiated by environmental stress and sustained by fecal factors in the cotton-top tamarin (Saguinus oedipus). Dig Dis Sci. 2000; 45:385-393.

44. Peck OC, Wood JD. Brain-gut interactions in ulcerative colitis. Gastroenterology. 2000;118:807-808.

45. Xia Y, Hu HZ, Liu S, Pothoulakis C, Wood JD. Clostridium difficile toxin A excites enteric neurones and suppresses sympathetic neurotransmission in the guinea pig. Gut. 2000;46: 481-486.

46. Fang X, Liu S, Wang XY, et al. Neurogastroenterology of tegaserod (HTF 919) in the submucosal division of the guinea-pig and human enteric nervous system. Neurogastroenterol Motil. 2008;20: 80-93.

47. Fei G, Raehal K, Liu S, et al. Lubiprostone reverses the inhibitory action of morphine on intestinal secretion in guinea pig and mouse. J Pharmacol Exp Ther. 2010;334:333-340.

48. Wood JD. Taming the irritable bowel. Curr Pharm Des. 2013; 19:142-156. 